\title{
Comments
}

\section{THE SUPREME COURT'S BILL OF ATTAINDER DOCTRINE: A NEED FOR CLARIFICATION}

It is all very pleasant to say that the remedy for bad laws lies with the people at the polls, but what Senators or Representatives were ever defeated because they voted for a sedition law? ... . If legislators are determined not to be guardians of the liberties of the people and if judges refuse to interfere when legislators take those liberties away, what is the use of putting guarantees of fundamental rights into the Constitution except, perhaps, to furnish political orators with noble words to quote while they tell us Americans to thank God that we are not as other men are? ${ }^{1}$

Professor Chafee wrote the above to protest the threat to personal liberties posed by the flood of anti-Communist legislation that poured out of Congress during the late 1940's and early 1950's. He was particularly concerned that the Supreme Court, during the same period, was eroding one of its most effective weapons for keeping such legislation within constitutional bounds. ${ }^{2}$ That weapon is the bill of attainder clauses $^{3}$ which trace their origin to the parliamentary excesses generated by centuries of political dissension and unrest in England. The erosion that concerned Professor Chafee lias now been halted, but the bill of attainder clauses remains an uncertain protection against legislation aimed at political dissidents.

Toward the end of its 1964 Term, the Supreme Court ruled in United States v. Brown $n^{4}$ that section 504 of the Labor-Management Reporting and Disclosure Act of $1959,{ }^{5}$ which made it a crime for a Communist Party nember to hold umion office, was unconstitutional as a bill of attainder. The opinion's doctrinal basis alone made it a notable decision, for Brown was only the third Supreme Court opinion in history to draw upon the bill of attainder prohibition to invalidate a federal statute. ${ }^{\circ}$ Perhaps more significant, the Court in Brown made an abrupt and eniphatic departure from the narrow and technical attainder doctrine

1 Chafee, Three Hunan Rights in the Constitution of 1787, at 161 (1956).

2 Id. at 156-61.

3 U.S. CoNst. art. I, $\$ \$ 9,10$.

4381 U.S. 437 (1965).

573 Stat. 519, 536 (1959), 29 U.S.C. \$ 504 (1964).

6 Federal statutes were held invalid as bills of attainder in Ex Parte Garland, 71 U.S. (4 Wall.) 333 (1866), and in United States v. Lovett, 328 U.S. 303 (1946). The Court's basic bill of attainder doctrine was stated in Cummings v. Missouri, 71 U.S. (4 Wall.) 277 (1866), which struck down an amendment to the Missouri constitution. 
developed in the 1950's. However, Brown can properly be viewed as a - missed opportunity. It was the first case in nineteen years in which the Court faced the bill of attainder question to the exclusion of all other issues, ${ }^{7}$ and it offered the Court a unique opportunity to restate and clarify its attainder doctrine as a meaningful constitutional safeguard. This opportunity was missed, and the bill of attainder doctrine emerges from the Brown decision as simply a protection against statutes drawn too narrowly and specifically. The doctrine was not placed on a foundation that would make it a constitutional bulwark against the inherent evils of bills of attainder.

The thesis of this Comment is that the constitutional proscription of bills of attainder is a guarantee of procedural due process and that the primary weakness of the Court's current attainder doctrine is its failure to recognize this expressly. The Comment will trace the historical development of the attainder doctrine, analyze the sources of confusion in the Court's current doctrine, and suggest why a frank avowal of the procedural due process theory would make the bill of attainder prohibition a more ineaningful constitutional protection.

\section{I}

THE HISTORICAL DEVELOPMENT

\section{A. Terminology}

A bill of attainder is defined by the Supreme Court as a legislative act which inflicts punishment on named individuals or members of an easily ascertainable group without a judicial trial. ${ }^{8}$ This definition has its roots in English common law and parliamentary history. At English common law attainder was an "inseparable consequence" of a death sentence imposed by the courts. ${ }^{\circ}$ The added penalty of attainder proceeded on the theory that

when it is . . clear beyond all dispute, that the criminal is no longer fit to live upon the earth, but is to be exterminated as a monster and a bane to human society, the law sets a note of infamy upon him ... and takes no farther care of him than barely to see him executed. $\mathrm{He}$ is then called attaint, attinctus, stained or blackened .... [B]y an anticipation of his punishment, he is already dead in law..$^{10}$

The consequences of attainder were the forefeiture of the attainted person's real and personal property ${ }^{11}$ and the corruption of his blood,

7381 U.S. at 440.

8 United States v. Lovett, 328 U.S. 303, 315-16 (1946), cited with approval in United States v. Brown, 381 U.S. 437, 448-49 (1965).

94 BLACKSTONe, CoMOMENTARIES *380.

10 Ibid.

11 Id. at $* 381$. 
the latter consequence meaning he could not inherit and no one could inherit from him. ${ }^{12}$ The attainted was "wiped out as if he had never been born." 13

Because acts of Parliament which imposed a death sentence on a particular individual also carried an attainder, these special statutes were called acts of attainder. Similar statutes which prescribed a penalty short of death, such as banishment or loss of office, were called bills of pains and penalties. ${ }^{14}$ The Supreme Court lias consistently ruled that the constitutional proscription of bills of attainder encompasses bills of pains and penalties, ${ }^{15}$ and, unless indicated otherwise, the tern bill of attamder is used in its generic sense in this Comment.

\section{B. The English Experience}

The origin of bills of attainder in England is obscure, ${ }^{16}$ but their use was established by the fourteenth century. ${ }^{17}$ Bills of attainder were first used to escheat the estates of dead rebels who were beyond the reach of earthly justice. ${ }^{18}$ They gradually became convenient methods of dealing with living political enemies of the Crown and of Parliament who might be difficult to convict in a court of law. ${ }^{10}$ The initiative in proposing a bill of attainder originally rested with the King, but Parliament gradually assumed the initiative as its power grew. ${ }^{20}$

A typical bill of attainder had four essential characteristics: (1) it identified the victim by name; (2) it recited his actions which Parliament felt deserved punishment; (3) it contained a declaration of guilt; and (4) it prescribed the punislment. ${ }^{21}$ Not all bills of attainder followed

12 "[A]n attainted person can neither inherit lands ... nor retain those he is already in possession of, nor transmit them by descent to any heir . . . ." Id. at *388.

13 Chafee, op. cit. supra note 1 , at 96.

14 Id. at 97 .

15 E.g., Cummings v. Missouri, 71 U.S. (4 Wall.) 277, 323 (1867); Umited States v. Brown, 381 U.S. 437, 447 (1965).

16 ChafeE, op. cit. supra note 1 , at 98.

17 Id. at 102 .

18 Potter, OUtinne of ENgise Legal History 100 (5th ed. 1958). See also the Attainder of Jack Cade, quoted in Chafee, Documants on Fundammental Human Rights 651 (Prelim. ed. 1954).

10 POTIER, op. cit. supra note 18.

20 Davis, United States v. Lovett and the Attainder Bogey in Modern Legislation, 1950 WASE. U.L.Q. 13, 14. This turnabout was not without its embarrassments to English kings. See, e.g., the account of the attainder of the Earl of Strafford in Crafree, THREe Hunar RIGHTS IN THE CONSTITUTION OF 1787, at 109-13 (1956). King Henry VIII is given the greatest credit for making bills of attainder an accepted method of dealing with political enemies. See Maitiand, The Constitutional History of Engiand 216 (1913).

21 These characteristics are illustrated by the attainder of the Earl of Kildare (the English has been modernized): "Forasmuch as Thomas Fitzgerald Earl of Kildare in Ireland ... 
this model, however. Some imposed punishment not on a named individual or named individuals but on an easily ascertainable group of persons. ${ }^{22}$ Some were conditional, imposing the punishment not so much for a past act as for the failure to perform a certain act in the future. ${ }^{23}$ Many bills of attainder, while purporting to impose punishment for past deeds, had largely preventive purposes. They were designed to remove a pohtical enemy before he became powerful enough to pose a real threat to the King or to Parliament. ${ }^{24}$

Bills of attainder were creatures of expediency and eventually fell into disuse. The last person executed in England under the authority of a bill of attainder was Sir John Fenwick, wlo was part of the abortive plot to assassinate King William III in $1696 .{ }^{25}$ The last attempt by Parliament to inflict punishment by statute on a named individual was the bill of pains and penalties brought against Queen Caroline, wife of King George IV, in $1820 .{ }^{26}$ Parliament, however, still retains the legal

falsely and traitorously has not only levied war in ... towns and places within the king's said Dominion of Ireland against our said Sovereign Lord . . . and has nost traitorously violently and cruelly slain murdered and killed diverse of the true and faithfnl Subjects of our said Sovereign Lord within his said Dominion of Ireland, and also there has taken spoiled and broken ... Castles [and] Fortresses ... of our said Sovereign Lord and out of them has falsely and traitorously taken spoiled and borne away ... guns and other artillery munitions ... of war of our said Sovereign Lord . . . BE IT therefore enacted by the authority of this present Parliament that the said Earl be attainted adjudged and convicted of High Treason and lose his name title style dignity and preeminence of Earl of Kildare and all other of his estate style dignity and preeminence what so ever." 26 Hen. 8, c. 25 (1534).

22 See, e.g., the Attainder of the Earl of Kildare, supra note 21, which also attainted "all such persons which be or hereafter have been comforters abettors partakers confederates or adherents unto the said Earl ...."

${ }^{23}$ See, e.g., 17 Car. 2, c. 5 (1665); Chafee, Docunents on Fundamental human Rigers 669 (Prelim. ed. 1954) (Attainder of the Earl of Danby).

24 Chafee, Thres Human Rigits IN THE Constitution of 1787, at 103-04 (1956).

25 MaITLAND, op. cit. silpra note 20, at 319. Professor Chafee notes that Lord Edward Fitzgerald, leader of the 1798 rebellion in Ireland, was the last person condemned to death by an act of Parliament. But he died in prison while awaiting execution. CHAFEE, op. cit. supra note 24 , at 136 .

26 The bill accused the Queen of infidelity. CrafFe, op. cit. supra note 24, at 136-37. The bill carried by a majority of just nine votes on the third reading, prompting Lord Liverpool to move that further consideration be postponed for six months. 3 TRIAT OF QUEEN CAROLINE 479 (1820). The bill was never revived. The aging Lord Erskine, who had argued vigorously against the bill, was elated at the decision to postpone further consideration: "I see the fate of this odious measure consummated .... [and] I heartily rejoice in this event. My Lords, I am an old man; and my life, whether it llave been for good or evil, has been passed under the sacred rule of law. In this moment I feel my strength renovated and repaired by that rule being restored. The accursed charge wherewithal we had menaced has passed over our heads. There is an end of that horrid and portentous excrescence of a new law-retrospective, and iniquitous, and oppressive; and the Constitution and scheme of our polity is once more safe." Id. at 480. 
authority to pass a bill of attainder should it overcome the moral pressure which has stayed its hand for more than a century. ${ }^{27}$

\section{The Colonial Experience and the Constitution}

During and following the Revolutionary War, each of the thirteen colonies adopted bills of attainder directed at persons who remained loyal to England during the conflict. ${ }^{28}$ Most of these were in the nature of bills of pains and penalties, confiscating the property of the Tories and banishing them fron the particular colony. But some were conditional attainders prescribing the penalty of death. ${ }^{29}$

There is bitle direct evidence to indicate why the bill of attainder proscription was placed in the body of the Constitution. ${ }^{30}$ The bill of attainder clauses were adopted without discussion and the debates of the Constitutional Convention shed no light on the action. ${ }^{31}$ This dearth of direct evidence may explain the Supreme Court's failure to adopt an attainder doctrime aimed at the inherent evils of those legislative enactments. ${ }^{32}$ It should be noted, however, that the Constitution contains two bill of attainder prohibitions, one directed at Congress ${ }^{33}$ and the other at the states..$^{34}$ The reasons advanced to support the prohibition on Congress do not necessarily support the restraint on the states.

The Supreme Court adopted the view in Brown that the bill of at- ' tainder clause was an important element in the scheme of separated

2721 Halsbury, The Laws of Engrand 727 (1912). The Forefeiture Act of 1870, 33 \& 34 Vict., c. 23, however, has abolished attainder as a consequence of conviction for treason of felony in a court of law. 1 StepHen, Commentaries on tHe Laws of England 334 (Jenks ed. 1914). This has been achieved in the United States by article III, $\S 3$ of the Constitution.

28 See Van Tyne, The Loyauists in the Amejucan Revolution (Apps. $B$ and C) (1902) for a compilation of the bills of attainder passed by the colonial legislatures during and following the Revolutionary War.

29 Sce, e.g., 5 Acts and Resolves of the Province of Massachusetts Bay 770 (1886); 4 Statutes at Large of South Caroltna 450 (Cooper ed. 1838); 9 Hentag's Statutes at LARGE OF VIRGINIA 463-64 (1821).

${ }^{30}$ It scems significant, however, that the bill of attainder clause was adopted by the Constitutional Convention while nuany of its members continued to doubt the wisdom of including a bill of rights in the Constitution. See Cggley, Constiturional Lmmitations 365-68 (7th ed. 1903), THE FeDeraIIST, No. 84 (Hanilton). This would suggest that such a restraint was deemed of more fundamental importance to individual biberty than the protections later incorporated in the Bill of Rights, at least in the view of some of the framers of the Constitution.

31 See Madison, Journal of the Federat Convention 586, 727-28 (Scott ed. 1893).

82 United States v. Brown, 381 U.S. 437 (1965), is the only Supreme Court opimion to inquire in any detail into the precise reasons for the inclusion of the bill of attainder prohibition in the body of the Constitution. Id. at 442-46.

33 "No Bill of Attainder or ex post facto Law shall be passed." art. I, § 9.

34 "No State shall . . . pass any Bill of Attainder . . . ." art. I, § 10. 
powers established by the Constitution.$^{35}$ A close reading of The Federalist dealing with the separation of powers supports this position, ${ }^{36}$ although the separation of powers argument is framed in general terms and nowhere makes reference to the bill of attainder prohibition on Congress. Madison was clearly concerned with the potential threat to liberty of an overly powerful legislative brancl in the control of a tyranmical majority:

The legislative department is every where extending the sphere of its activity, and drawing all power into its impetuous vortex. The founders of our republics .... seem never to have recollected the danger from legislative usurpations, which, by assembling all power in the same hands, must lead to the same tyranny as is threatened by executive usurpations .... [W] [Were the legislative power is exercised by an assembly, which is inspired by a supposed influence over the people, with an intrepid confidence in its own strength; which is sufficiently numerous to feel all the passions which actuate a multitude; yet not so numerous as to be incapable of pursuing the objects of its passions, by means which reason prescribes; it is against the enterprising ambition of this department, that the people ought to indulge all their jealousy, and exhaust all their precautions. ${ }^{37}$

A legislature approving a bill of attainder is properly viewed as exercismg a judicial function, substituting "legislative determination of guilt and legislative imposition of punisliment for judicial finding and sentence."38 The bill of attainder prolibition as it applies to Congress is, therefore, consistent with the notion that a legislative body should exercise only legislative powers in a government of separated powers. ${ }^{39}$ Since the Constitution prescribes no sclieme of separated powers for state governments, the second constitutional proscription of bills of attainder must be based on a different rationale. Madison describes this restriction of state power as a "constitutional bulwark in favor of personal security and private rights." ${ }^{40}$ Professor Chafee suggests a more practical basis, connecting the attainder prohibition on the states with article VI of the Constitution, which makes treaties the supreme law of the land. The Treaty of 1783 liad souglit to restore friendly relations with Great Britain partly by assuring fair treatment to those in the

35381 U.S. at 442-47; Comment, 72 YaIE L.J. 330, 342-48 (1962).

36 THE FederaIIST, Nos. 47-51 (Madison).

37 Id., No. 48, at 310-11 (1818) (Madison).

- 38 United States v. Lovett, 328 U.S. 303, 321-22 (1946) (concurring opinion). "An Act of Attainder, although it is a legislative enactment, is the highest form of parbiamentary judicature ...."21 HALSBURY, op. cit. supra note 27, at 72\%. See also Calder v. Bull, 3 U.S. (3 Dall.) 386,389 (1798).

38 See notes 198-99 infra and accompanying text for a further discussion of this explanation of the bill of attainder clause.

40 The Federalist, No. 44, at 218 (1818) (Madison). 
colonies who had reniained loyal to the crown during the Revolutionary War.

The framers knew that the restoration of commerce with Great Britain was essential to our prosperity. Treaty violations, especially [statelegislative] confiscations of Tory property and annihilation of debts to Tories, were bad obstacies to friendly intercourse with the mother country. Consequently, the framers made assurance doubly sure by ènabling the national government to strike at such violations both through the clause making treaties supreme and the clause making acts of attainder void.41

The silence of the franiers on the reasons for the attainder prohibition necessarily nuakes the search for a rationale a speculative task. One point seems clear, however. Overemphasis on the relationship of the bill of attainder clause to the separation of powers doctrine tends to ignore a nore basic question of why acts of attainder fell into disuse in England, where there is no separation of powers.

\section{The Supreme Court And Bills of Attainder}

The bill of attainder clauses were not used by the Supreme Court as a check on legislative power until the companion cases of Cummings $v$. Missourit and Ex Parte Garland, ${ }^{43}$ decided in the immediate post-Civil War period. Those two cases took a significantly different view of bills of attaimder than would be conpelled by a strict reading of history. First, the Court adopted dictum from Fletcher $v . P e c k^{44}$ and ruled that the bill of attainder prohibition included bills of pains and penalties. ${ }^{45}$ Second, the Court used a definition of bill of attainder which omitted two characteristics of typical English acts of attainder. "A bill of attainder is a legislative act which inflicts punishment without a judicial trial." ${ }^{30}$ Absent are the requirements of a recital of the wrongs for which the punishment is inflicted and a legislative declaration of guilt. ${ }^{47}$ These omissions make the bill of attainder prohibition applicable to a broader category of statutes.

Cummings involved a challenge to an 1865 amendment to the Missouri

41 CHAFEe, op. cit. supra note 24 , at 97-98.

4271 U.S. (4 Wall.) 277 (1866).

43 Id. at 333 .

44 "A bill of attainder may affect the life of an individual, or may confiscate his property, or may do both." 10 U.S. (6 Cranch) 87,138 (1810).

45 Cummings v. Missouri, 71 U.S. (4 Wall.) 277, 323 (1866).

$40 \mathrm{Ibid}$. The element of a named individual or members of an easily ascertainable class is absent from this definition, but this element is implicit in the opinion and is specifically. included in later decisions. See, e.g., United States v. Lovett, 328 U.S. 303, 315-16 (1946); United States v. Brown, 381 U.S. 439, 448-49 (1965).

47 See text accompanying note 21 supra. 
constitution requiring public officials, teachers, lawyers, clergymen, and others to take a test oath as a condition of pursuing those careers. The person taking the oath was, in effect, required to swear under penalty of perjury that he had in no way inanifested support or sympathy for the Confederacy during the Civil War. The petitioner was a Roman Catholic priest who had been jailed for failing to take the oath. The Court held the test-oath requirement was a bill of attainder because it

was exacted, not from any notion that the several acts designated indicated unfitness for the callings, but because it was thought that the several acts deserved punishment, and that for many of them there was no way to inflict punishment except by depriving the parties, who had committed them, of some of the rights and privileges of the citizen. ${ }^{48}$

The state attempted to defend the test oath against the bill of attainder challenge by arguing that denial of the right to pursue a profession did not constitute punishment. The state contended that "to punish one $\ldots$ is to deprive him of life, hberty, or property. To take froin him anything less than these is no punishment at all." ${ }^{\prime 49}$ The Court flatly rejected this narrow view of punishment:

The deprivation of any rights, civil or political, previously enjoyed, may be punishment, the circumstances attending and the causes of the deprivation determining this fact. ...

The theory upon which our political institutions rest is, that all men have certain inalienable rights-that among these are life, liberty, and the pursuit of happiness; and that in the pursuit of happiness all avocations, all honors, all positions, are alike open to every one .... Any deprivation or suspension of any of these rights for past conduct is punishment, and can be in no otherwise defined. ${ }^{50}$

The Court noted it was not significant that the state had not declared the petitioner guilty of a crime or of disloyalty. The only difference between an express declaration of guilt in a statute and the absence of such a declaration in the test oath under review is that the latter "assumes the guilt and adjudges the punishment conditionally." 51

The Garland decision held unconstitutional an 1865 act of Congress prescribing a test oath similar to that in Cummings for attorneys practicing in federal courts. The Court based its bill of attainder ruling largely on the authority of Cummings, holding that the test oath

operates as a legislative decree of perpetual exclusion. And exclusion from any of the professions or any of the ordinary avocations

\footnotetext{
4871 U.S. (4 Wall.) at 320.

$49 \mathrm{Id}$. at 298. (All italicized in original.)

50 Id. at 320-22; cf. Bradwell v. Tllinois, 83 U.S. (16 Wall.) 130, 139 (1872).

5171 U.S. (4 Wall.) at 325.
} 
of life for past conduct can be regarded in no other light that as punishment for such conduct. . . . All enactments of this kind partake of the nature of bills of pains and penalties, and are subject to the constitutional inhibition against the passage of bills of attainder $\ldots . .^{52}$

Four justices wrote a single dissent to the Cummings and Garland decisions. ${ }^{53}$ They first challenged the majority's assertion that the denial of the right to practice law constitutes punishment. ${ }^{54}$ They then applied a technical bill of attainder test to the oaths under review in both cases. The dissenters noted that English bills of attainder customarily singled out their victims by name or description, contained a declaration of guilt, pronounced sentence, and inflicted punishment. ${ }^{55}$ Finding none of these characteristics in the test oaths, the dissenters contended they "can in no sense be called ... bills of attainder."

The Cummings and Garland decisions were reaffirmed as the basic statement of the Court's bill of attainder doctrine five years later when a West Virginia statute conditioning access to the state's courts on the taking of a Cummings-type test oath was held unconstitutional in a twosentence opinion. ${ }^{57}$ On two occasions prior to 1900 , the Court was forced to distinguish the Cummings and Garland holdings. In Dent v. West Virginia, ${ }^{58}$ a statute establishing minimum qualifications for physicians was challenged, inter alia, as a bill of attainder. The Court, in rejecting the claim, noted that the test oath invalidated in Cummings, because it had no bearing on a person's qualifications for a particular profession, constituted punishment. The same could not be said for a statute requiring that an aspiring physician graduate from an accredited medical school before being licensed to practice medicine. ${ }^{50}$ In Hawker $v$. New York, ${ }^{00}$ the bill of attainder challenge was directed at a New York statute denying a license to practice medicine to any person who had been convicted of a felony. Petitioner had been convicted of abortion prior to passage of the act and his license had been revoked under the authority of the act. ${ }^{01}$

52 Ex Parte Garland, 71 U.S. (4 Wall.) 333, 377 (1866).

53 Id. at 382 .

G4 Id. at 384-86.

55 Id. at 389 .

58 Id. at 390 .

57 Pierce v. Carskadon, 83 U.S. (16 Wall.) 234 (1872).

58129 U.S. 114 (1889).

59 The bill of attainder challenge was totally irrelevant in this case. The statute did not contain the specificity necessary for finding a bill of attainder. See text accompanying notes 136-46 infra. The challenged statute was properly upheld under the due process clause of the fourteenth amendinent.

60170 U.S. 189 (1898).

62 Petitioner's strongest argument in Hawker was that the statute operated as an ex post facto law as applied to him. The three dissenting justices would have held for petitioner on that ground. 170 J.S. at 200-05. The majority dismissed the ex post facto argument by 
The Court used the same reasoning it had in Dent to reject the bill of attainder argument.

For all practical purposes, however, the bill of attainder clause remained dormant as a check on legislative power for three quarters of a century. ${ }^{02}$ After World War II, the bill of attainder clause assumed new significance, becoming an important weapon in the legal challenges made against the legislation that grew out of the congressional concern with Communism and national security. Appropriately enough, it was legislation inspired by Representative Martin Dies, the first chairman of the House Committee on Un-American Activities, that pumped new life into the bill of attainder clause.

On February 1, 1943, Dies denounced, in a speech on the floor of the House, thirty-nine named government officials as "crackpot" and "radical" bureaucrats and members of Counmunist-front organizations. ${ }^{.3}$ He proposed that Congress withhold appropriations that would pay the salaries of the men he named. After some debate a special subcommittee of the Appropriations Committee was appointed to investigate the charges. The subcommittee returned a verdict of guilty of subversive activity against three of the men Dies had named. ${ }^{64}$ The House approved a rider to the Urgent Deficiency Appropriation Bill of $1943^{\circ 5}$ directing that after a specified date no appropriation in the bill be made available to pay the salaries of the three named officials. The Senate tried to delete the rider from the bill, but the House insisted it be retained. The Senate relented under the pressure of the need for funds to continue the war effort, and the rider was approved. President Roosevelt signed the bill, but pointedly expressed his behef that the rider was unconstitutional..$^{\circ 6}$

claiming the state, by enacting the statute, "is not seeking to further punish a criminal, but only to protect its citizens from physicians of bad character." Id. at 196.

02 This statement is accurate as it applies to the Supreme Court. The bill of attainder argument has been urged in numerous state court cases, particularly in the period between the Civil War and World War II. This Comment, however, is concerned only with the bill of attainder doctrine developed by the Supreme Court. State court bill of attainder rulings are surveyed in Comment, 63 YaLe L.J. 844 (1954), and Comment, 72 Yale L.J. 330 (1962).

0389 Cong. Rec. 474-86 (1943). See generally Schuman, Bill of Attainder in the 78th Congress, 37 Axr. PoL. ScI. REv. 819 (1943).

04 United States v. Lovett, 328 U.S. 303, 311 (1946). The three nen were Robert M. Lovett, the Government Secretary of the Virgin Islands, and Goodwin B. Watson and William E. Dodd, Jr., both employees of the Federal Communications Commission.

05 57 Stat. 431, 450 (1943).

00 Professor Chafee notes that the House, in approving the rider, faced a dilemma that often led to the enactnent of bills of attainder in Parbiament. The House wanted to get rid of certain officials in the executive branch. The Constitution gives Congress this power under impeachnent procedures. art. I, $\S 3$. But here the House lacked the legal basis to initiate impeachment proceedings. See art. $H, \S 4$. So it chose the expediency of cutting off the salaries of the three men by means of the rider. See CEAFEE, supra note 24, at 148-51. 
Thus, for the only time in its history, Congress had named the individuals who would be subject to a statutory penalty. The Supreme Court had little trouble striking down the rider as unconstitutional in United States v. Lovett. ${ }^{0 \tau}$ Justice Black, writing for six inembers of the Court, said the rider "falls precisely within the category of Congressional actions which the Constitution barred by providing that 'No Bill of Attainder or ex post facto Law shall be passed." "'08 The officials whose salaries were stopped were identified by name. The punishment was of the same nature as that present in the test oaths invalidated in Cummings and Garland. The three officials were excluded from government service, and the stigma the rider placed on them could make that exclusion permanent. There was no judicial intervention. The sanction went into effect automatically with the President's signing of the bill.

Black's opinion contains a clear suggestion of a procedural due process basis for the Court's bill of attainder doctrine. He noted that "the effect [of the rider] was to inflict punishment without the safeguards of a judicial trial . . . ." All subsequent bill of attainder decisions ignored this portion of the Lovett opinion, however.

Because of the nature of the statute invalidated in Lovett, it might be expected that the bill of attainder holding would cause little disagreement in the Court. But Justice Frankfurter, joined by Justice Reed, wrote a concurring opmion ${ }^{70}$ which concluded that the statute was not a bill of attainder. ${ }^{71}$ The Frankfurter opinion was to have the more profound impact on the developinent of the Court's bill of attainder doctrine in subsequent decisions, and therefore warrants detailed examination.

Frankfurter started with the proposition that the bill of attainder prohibition fell into the category of specific constitutional concepts which are "defined by history"72 and which allow very little room for individual legal judginent. Frankfurter's examination of history convinced hin that the rider to the Urgent Deficiency Appropriation Bill lacked two essential characteristics of bills of attainder.

67328 U.S. 303 (1946).

68 Id. at 315 .

${ }^{69} \mathrm{Id}$. at 317. (Emphasis added.)

$70 I d$. at 318 .

71 Justice Frankfurter concurred in the result of the majority's decision, the result being that the government was required to pay the back salaries of the three respondents and restore them to the regular payroll. But his concurrence was based on a narrow contract theory. He viewed the rider as preventing the ordinary disbursal of money to pay the salaries of the respondents. "It did not cut off the obligation of the Government to pay for services rendered and the respondents are, therefore, entitled to recover the judgment which they obtained from the Court of Claims." Id. at 330. The respondents had stayed on in their posts after passage of the rider and then sued in the Court of Claims for back salaries. The Court of Claims held for respondents on the same ground that Frankfurter would have.

72328 U.S. at 321 . 
First, the rider neither specifed the offense of which the three officials were deemed guilty nor contained a declaration of their guilt. ${ }^{73}$ The Constitution, Frankfurter noted, was framed at a time when legislatures frequently exercised judicial functions. Bills of attainder were of a judicial nature partly because, on their face, they carried a declaration of guilt. It was not enough, in his view, that a statute affected named individuals.

Second, the rider also lacked "the imposition of punishment in the sense appropriate for bills of attainder."74 For Frankfurter, the only punishment appropriate in the bill of attainder context was retribution for past acts. It was not enough that a statute imposed a deprivation. The deprivation inust be accompanied by a legislative intent to punish. The rider, on its face, did not express a punitive intent, and resort to legislative history would not correct the deficiency. Frankfurter conceded the House might well have been motivated by a desire to punish the three named officials. But, "to hold that a measure which did not express a judgment of condemnation by the Senate and carried an affirmative disavowal of such condemnation by the President constitutes a bill of attainder, disregards the historic tests for determining what is a bill of attainder." 75 Frankfurter read the rider simply as a congressional judgment, without any punitive motive, that the three named officials should not be paid. ${ }^{76}$

Frankfurter's view, emphasizing the form of a statute rather than its substance, soon became the majority view as the Court considered bill of attainder challenges to antisubversive legislation that emerged in the late 1940's and early 1950's. The first departure from the broader, less formalistic views of attainder contained in Cummings, Garland and Lovett came in American Communications Ass' $n$ v. Douds. ${ }^{77}$ The Court

73 This is a combination of elements (2) and (3) discussed in the text accompanying note 21 supra.

74328 U.S. at 323.

75 Id. at 325 .

${ }^{70}$ It is somewhat difficult to reconcile Frankfurter's very narrow historical view of bill of attainder with his implicit approval of the Cummings and Garland opinions. Toward the end of his concurring opimion in Lovett, Frankfurter distinguishes those two earlier decisions and indicates his belief that the two test oaths invalidated in those cases were bills of attainder in the classic sense. 328 U.S. at 327. Yet those test oaths lacked an element that Frankfurter felt was essential to a bill of attainder-a declaration of guilt on the face of the statute. The Cummings opimion specifically ruled that an express declaration of guilt was not essential. It was sufficient that the oaths "assume the guilt." See note 48 supra. This apparent contradiction in Frankfurter's opinion miglt well bave stemmed from his realization that it was too late to turn back the clock and change the Cummings and Garland opimions. In fact, there is a hint in Frankfurter's opinion that le would have joined the dissenters in those two earlier decisions had he been on the bench at that time. He describes the dissent to those cases as "powerful," 328 U.S. at 327 n.2, and that dissent elosely parallels the position taken by Frankfurter in Lovett.

77339 U.S. 382 (1950). A major portion of the majority decision is devoted to a first 
there upheld the constitutionality of section $9(\mathrm{~h})$ of the Labor Management Relations Act of $1947,{ }^{78}$ which required union officers to submit affidavits swearing they were not members of the Communist Party or of any organization which advocated the forceful overthrow of the government. If an officer failed to submit such an affidavit, his union was denied access to the facilities of the National Labor Relations Board. ${ }^{70}$ The petitioner argued that the loyalty oath requirement operated to exclude members of an easily ascertainable group from certain occupations because of loyalties and beliefs, and therefore section $9(\mathrm{~h})$ contained the same objectionable features as the acts invalidated in Cummings, Garland and Lovett. ${ }^{80}$ The Court, however, found two grounds for distinguishing the three earher cases.

First, the individuals involved in the earlier decisions were in fact being punished for past actions. Section $9(\mathrm{~h})$, on the other hand, subjected certain union officers only to possible loss of position if they failed to conform to present standards of conduct required by Congress. ${ }^{81}$ The Court conceded that past conduct would determine on whom the sanctions would fall, "but that does not alter the conclusion that $\S 9(\mathrm{~h})$ is intended to prevent future action rather than to punish past action." ${ }^{\prime 2}$ Second, the deprivation imposed by the statute was neither permanent nor absolute. Any union officer could escape the sanctions simply by altering his loyalties, quitting the disfavored organization, and signing the affidavit. ${ }^{83}$ The Court concluded section $9(\mathrm{~h})$ did not impose punishment and, therefore, was not a bill of attainder.

In Garner v. Board of Pub. Works of Los Angeles, ${ }^{84}$ the Court held a loyalty oath required of all city employees did not constitute a bill of attainder. The statute in question barred from city employment those who would not affirm that they had not advocated the violent overthrow of the Government during the preceding five years, nor belonged to any group during that period which had during the preceding five years ad-

amendment challenge. $I d$. at 389-412. Only the Court's bill of attainder discussion is analyzed in this Comment.

7861 Stat. 136, 146 (1947), amending the National Labor Relations Act of 1935, 49 Stat. 449, as amended, 29 U.S.C. \$\$ 151-66 (1964).

7961 Stat. 136, 146 (1947).

80339 U.S. 382,413 (1950).

81 The required conduct was to submit the affidavits. The Court found that Congress had the power to require the affidavits under the commerce power. The purpose of $\S 9(\mathrm{~h})$ was to reduce the likelihood of a political strike interfering with the free flow of commerce. 339 U.S. at 387.

$82 I d$. at 414 .

83 Ibid.

84341 U.S. 716 (1951). 
vocated such action. ${ }^{85}$ Relying on Dent $v$. West Virginia ${ }^{86}$ and Hareker $v$. New York ${ }^{87}$ to distinguish Cummings, the Court ruled the Los Angeles oath requirement was not punitive. Rather, it was a legitimate exercise of legislative power to establish reasonable qualifications for public employment. $^{88}$ Unlike the test oath invalidated in Cummings, the Los Angeles loyalty oath did not sweep broadly across all categories of professions. Its applicability was confined to those in government service, and the Court found that loyalty was reasonably related to qualification for sucll employment. Lacking the element of punishment, the oath could not properly be labeled a bill of attainder.

Flemming v. Nestor ${ }^{89}$ represented the next significant development of the Court's bill of attainder doctrine..$^{90}$ The respondent, a resident alien for more than forty years, was deported in 1954 because he had been a member of the Communist Party during the 1930's. His Social Security benefits were terminated under section 202(n) of the Social Security Amendments of $1954,{ }^{91}$ which authorizes sucl termination for any alien deported because of Communist Party membership. The Court held section 202(n) did not constitute a bill of attamder because the deprivation imposed was not punislıment in a technical sense. The Court ruled first that deportation, the essential precondition to termination of

85 The oath, therefore, did not have the "escapability" feature emphasized in Douds. See text accompanying note 83 supra. The Court, however, did not feel this was a serious deficiency. The California legislature had, in 1941, amended the Los Angeles City Charter to bar from city employment anyone who had advocated, or had belonged to any organization which had advocated, the violent overthrow of the government. The charter amendment authorized the Los Angeles City Council to adopt legislation to implement the amendment. In 1948, acting upon that authorization, the City Council adopted the loyalty oath which imposed its disability on anyone who had engaged in the proscribed advocacy or organizational affiliation at any time after 1943. The Court reasoned that the charter amendment was already in effect at that time, providing adequate notice of the forbidden activities. "While the amendment deprived no one of employment with or without trial, yet from its effective date it terminated any privilege to work for the city in the case of persons who thereafter engaged in the activity proscribed." 341 U.S. at 721.

86129 U.S. 114 (1889).

87170 U.S. 189 (1898).

88341 U.S. at 723 .

89363 U.S. 603 (1960).

90 From the Douds to the Flemming decisions, there were at least eight other Supreme Court opimions in which the bill of attainder argument was considered by the majority, discussed by dissenters, or urged by the parties. See Joint Anti-Fascist Refugee Comm. v. McGrath, 341 U.S. 123, 144 (1951) (concurring opinion); Wieman v. Updegraff, 344 U.S. 183, 193 (1952) (concurring opimion); Linehan v. Waterfront Conm'n of New York Harbor, 347 U.S. 439, 441 (1954) (dissent); Barsky v. Board of Regents, 347 U.S. 442, 46061 (1954) (dissent); Peters v. Hobby, 349 U.S. 331, 337-38 (1955) (urged by petitioner); Uphaus v. Wyman, 360 U.S. 72, 108 (1959) (dissent); Barenblatt v. United States, 360 U.S. 109, 154-62 (1959) (dissent); and DeVeau v. Braisted, 363 U.S. 144, 160 (1960). None of these opinions added significantly to the development of the Court's bill of attainder doctrine.

0168 Stat. 1083, 42 U.S.C. \& 402(n) (1964). 
benefits, was not punishment but an exercise of Congress' plenary power over aliens..$^{92}$ The Court then held that the termination of benefits under section 202(n) was not punishment but "the mere denial of a noncontractual government benefit." ${ }^{\prime \prime 3}$ While the Court conceded Congress could not arbitrarily cut off an individual's Social Security benefits, ${ }^{94}$ it ruled section 202(n) could not be a bill of attainder because it did not inflict punishment as the Court defined the word. ${ }^{\text {s5 }}$

In Communist Party of the United States v. Subversive Activities Control $B d . .^{06}$ the Court's bill of attainder doctrine completed practically a full circle from the Lovett decision fifteen years earlier. Justice Frankfurter wrote the majority opinion in the Communist Party case, giving him the opportunity to assert his technical and formalistic view of bills of attainder as the view of the Court.97

The issue in the Communist Party case was the validity of an order issued by the Subversive Activities Control Board ordering the party to register with the Attorney General under the provisions of the Subversive

92 The Court rehed primarily on Fong Yue Ting v. United States, 149 U.S. 698 (1893), for this position. 363 U.S. at 616. In that earlier decision, the Court said: "The order of deportation is not a punishment for crime. It is not a banisliment, in the sense in which that word is often applied to the expulsion of a citizen from his country by way of punishment. It is but a method of enforcing the return to his own country of an alien who has not comphed with the conditions upon [which] . . . his continuing to reside bere shall depend." 149 U.S. at 730 (Emphasis added.); cf. Sherman v. Immigration and Naturalization Service, 350 F.2d 894 (2d Cir. 1965), rev'd on rehearing en banc, 34 U.S.L. WEEK 2393 (2d Cir., Jan. 17, 1966). This argument of the Court is analyzed in detail in the text acconspanying notes $162-66$ infra.

93363 U.S. at 617 . This conclusion followed from the Court's earlier finding that since the receipt of Social Security benefits was not contingent on the amount of contributions made to the fund, a beneficiary had no vested right to payments made from the fund. The majority's conclusion that the ternination of Social Security benefits is not punitive is put in some doubt by testimony of former Secretary of Health, Education and Welfare Marion Folsom before a Senate committee. Justice Douglas' dissent quotes Folsom as saying "the deprivation of benefits as provided in the amendment is in the nature of a penalty ...." Id. at 633 .

84 The Court found that $\S 202(n)$ bore a rational relationship to a legitimate legislative purpose and, therefore, the termination of benefits was not arbitrary. 363 U.S. at 617. The Court said one of the purposes of the Social Security benefits was to aid the national economy as a whole by imcreasing the purchasing power of the elderly. This purpose would be frustrated if the government were required to pay benefits to deported aliens who would not be spending their money in the United States. Id. at 612. Yet the Court does not consider the purpose of the legislation frustrated by the fact that not all deported aliens have their Social Security benefits terminated and that beneficiaries who voluntarily live abroad do not have their monthly checks halted. Id. at 620-21.

95 Id. at 613-21.

96367 U.S. 1 (1961).

${ }^{07}$ The Court was presented with a variety of coustitutional challenges, particularly on first and fifth amendment grounds. The discussion of the case in this Comment will be confined to the bill of attainder issue. 
Activities Control Act of $1950 .^{98}$ The party's bill of attainder argument proceeded on these grounds: The consequences of complying with the registration requirement were so onerous ${ }^{99}$ that Congress did not anticipate they would be complied with. The real purpose of the act, therefore, was to provide a pretext for prosecuting groups which refused to register. This satisfied the punishment element of a bill of attainder. Furthermore, the act was written in such a way that the party would inevitably be ordered to register. This satisfied the specificity requirement. ${ }^{100}$

Frankfurter rejected this argunient. He conceded that niany congressmen who voted for the act fully expected its operation to result in requiring the Communist Party to register. He noted, however, that Congress had deliberately declined to designate the party by name as an organization subject to the registration requirement. ${ }^{101}$ Instead, Congress wrote the statute in terms that attach the registration requirement "not to specified organizations but to described activities in which an organization may or may not engage."102 The determination of the organizations to be subjected to the statute's sanctions was left to the later determination of an administrative agency. The act, therefore, lacked the specificity essential to a bill of attainder.

Frankfurter also noted that the legal consequences of the statute attached only to present activities. Past conduct of an organization was pertinent only as probative of present activities. ${ }^{103}$ Thus, an important

9864 Stat. 987,50 U.S.C. $\$ \S 781-858$ (1964).

90 Among the consequences of registration: (1) Members of registered organizations are required to disclose their membership in seeking employment with the federal government or at any defense facility. 64 Stat. 992 (1950), 50 U.S.C. \& 784 (1964). (2) Members of registered organizations are to be denied passports. 64 Stat. 993 (1950), 50 U.S.C. \& 785 (1964). This section was held unconstitutional in Aptheker v. Secretary of State, 378 U.S. 500 (1964). (3) Registered organizations are required to identify publications sent through the mails or in interstate commerce as being disseminated by a "Communist organization." A sinilar label has to he attached to any radio or television broadcast sponsored by a registered organization. 64 Stat. 996 (1950), 50 U.S.C. $\$ 789$ (1964). (4) Contributions to registered organizations cannot be claimed as tax deductions. 64 Stat. $996-97$ (1950), 50 U.S.C. $\S 790$ (1964).

100367 U.S. at 82. This Comment is concerned only with the bill of attainder clause as it applies to acts of Congress. No position is taken on the questions of whether that constitutional proscription would be applicable to an administrative agency, such as the Subversive Activities Control Board, in its rule-making function or whether such an agency's adjudicative procedures would satisfy the procedural due process requirements of the bill of attainder clause.

101367 U.S. at $84-85$.

102 Id. at 86. The Board was to require registration of any organization it found was "substantially directed, dominated, or controlled by the foreign government or foreign organization controlling the world Communist movenent . . . and . . operates primarily to advance the objectives of such world Communist movement . . ." 64 Stat. 989 (1950), 50 U.S.C. $\$ 782$ (1964).

103367 U.S. at $86-87$. 
element in Frankfurter's technical view of attainder-the infliction of punishment for past acts-is missing. Further, any organization could at any time free itself from the sanctions of registration (and even the requirement of registration) by altering the course of conduct which brought it within the purview of the act.

Following the Communist Party decision, the Court's bill of attainder doctrine could only be described as confused. The Cummings, Garland, and Lovett decisions had not been overruled and still stood as the basic statement of the doctrine. None of those decisions had placed the doctrine firmly on a procedural due process basis. But they had made the attainder prohibition applicable to a broader category of statutes than a narrow reading of history would demand and had sought to assure that Congress could not achieve an attainder result by carefully framing a statute. However, the Court's implicit acceptance of Frankfurter's technical approach in the post-Lovett period, while paying lip service to the earlier decisions, made the attainder proscription an uncertain protection. The repeated efforts of the Court to distinguish the basic bill of attainder decisions in the post-Lovett period threatened to transform the attainder prohibition into a dead letter of the Constitution. ${ }^{104}$ This was the state of the law when the Court undertook a reexamination of its bill of attainder doctrine in 1965.

\section{II}

\section{The Brown CASE}

At first glance, United States v. Brown ${ }^{105}$ did not seem a promising vehicle for a shift in emphasis in the Court's bill of attainder doctrine. The statute under review, section 504 of the Labor-Management Reporting and Disclosure Act of $1959,{ }^{106}$ had been enacted by Congress to

104 See text accompanying notes 153-71 infra for a detailed analysis of the inroads the post-Lovett cases made on the Court's bill of attainder doctrine. It should be noted at this point that the post-Lovett cases managed to narrow the attainder doctrine into virtual im. potence by redefining what constituted "punishment" in a bill of attainder context.

105381 U.S. 437 (1965).

10673 Stat. 519, 536 (1959), 29 U.S.C. § 504 (1964). That section provides:

(a) No person who is or has been a member of the Communist Party or who has been convicted of, or served any part of a prison term resulting from his conviction of, robbery, bribery, extortion, embezzlement, grand larceny, burglary, arson, violation of narcotics laws, murder, rape, assault with intent to kill, assault which inflicts grievous bodily injury ... or conspiracy to commit any such crimes, shall serve-

(1) as an officer, director, trustee, member of any executive board or similar governing body, business agent, manager, organizer, or other employee (other than an employee performing exclusively clerical or custodial duties) of any labor organization, or

(2) as a labor relations consultant to a person engaged in an industry or activity affecting commerce, or as an officer, director, agent, or employee (other than as 
replace the statute held constitutional in the face of an attainder challenge in Douds. ${ }^{107}$ Respondent had been a member of the Communist Party for more than twenty-five years and had made no secret of his membership. ${ }^{108}$ He was elected to the executive board of Local 10 of the International Longshoremen's and Warehousemen's Umion in 1959, the same year that section 504 became law. He continued to hold that position through his 1961 trial and conviction under section 504. ${ }^{109}$ The court of appeals reversed the conviction, holding section 504 unconstitutional on first and fifth amendment grounds. ${ }^{110}$ The Supreme Court's opinion states at the outset that its conclusion that section 504 was void as a bill of attainder made it unnecessary to consider the first and fifth amendment issues. ${ }^{111}$

The majority opinion in Brown rests firmly on the broad view of attainder developed by Cummings, Garland, and Lovett. Those cases are principally relied on by the Court, with the post-Lovett cases cited only for purposes of distinguisling then. The majority's survey of history convinced it that "the Bill of Attainder Clause was not to be given a narrow historical reading . . . but was instead to be read in light of the evil the Franiers had souglit to bar: legislative punishment, of any form or severity, of specifically designated persons or groups."112

The majority held that the designation by section 504 of Communist Party members as the persons who could not hold union office without incurring criminal penalties made the statute a bill of attainder. Congress had not exercised its proper function of general rule-making, leaving it to the courts to determine who should be subject to the sanctions of the statute. Rather, Congress liad specified upon whom the deprivation should fall. The Court, in effect, said the statute possessed the dual evil

an employee performing exclusively clerical or custodial duties) of any group or association of employers dealing with any labor organization, during or for five years after the termination of his membership in the Coinmunist Party, or for five years after such conviction or after the end of such imprisonment ....

(b) Any person who willfully violates this section shall be fined not more than $\$ 10,000$ or imprisoned for not more than one year, or both.

The Brown case is concerned only with those portions of the section relating to Communist Party membership. The provisions dealing with prior criminal convictions are discussed in the text accompanying notes 176-77 infra.

107381 U.S. at 438-39.

108 Brief for Respondent, p. 4, United States v. Brown, 381 U.S. 437 (1965).

109 Respondent was sentenced to six months in prison following his conviction. 381 U.S. at 440 .

110 Brown v. Umited States, 334 F.2d 488, 496 (9th Cir. 1964). The bill of attainder issue was presented in the briefs and oral arguments before the Nimth Circuit but is not considered at all in the opinion. Letter froin Richard Gladstein, counsel for respondent, to Charles H. Wilson, Jr., Oct. 29, 1965.

111381 U.S. at 440.

112 Id. at 447 . 
of being underinclusive and overinclusive. ${ }^{113}$ It was underinclusive because, by limiting its reach to Communist Party members, its coverage did not extend to all persons tainted with the evil that Congress fearedthe likelihood of calling political strikes. At the same time, the act was overinclusive because it wrongly assumed all Communist Party members would be likely to call political strikes if placed in positions of power in unions. ${ }^{114}$

The Government attempted to rebut the bill of attainder challenge by arguing that the deprivation inposed by section 504 did not constitute punishment. The Government, citing Douds, contended section 504 was enacted for preventive, not retributive, reasons and did not impose its sanctions for past conduct. ${ }^{115}$

The Court distinguished Douds on the difference in wording between section 504 and section $9(\mathrm{~h})$. The five-year provision of section 504, not present in section $9(\mathrm{~h})$, made it impossible for a Communist Party member to escape the deprivations of the act by a simple alteration of loyalties. Furthermore, the Court was not impressed with the argument that a punishment had to have a retributive purpose to bring the act imposing the punishment within the bill of attainder category. "Punishment serves several purposes: retributive, rehabilitative, deterrent-and preventive."116 The Court noted that many English bills of attainder were largely preventive in purpose. ${ }^{117}$

Justice White, writing for the four dissenters, is deeply disturbed by the majority opinion. For one thing, lie feels the Douds decision is "obviously overruled." $118 \mathrm{He}$ also notes that the underinclusiveness and overinclusiveness which the majority finds in section 504 can be found in many other statutes wlich have been lield constitutional. He specifically inentions conflict-of-interest statutes ${ }^{110}$ and the statute held constitutional in Hawker v. New York. ${ }^{120}$ White feels the majority's ruling

113 The majority opinion does not use this terminology, but the dissent properly uses it to characterize the majority's analysis. Id. at 464 . This terminology is normally associated with equal protection doctrine. See Tussman \& tenBroek, Equal Protection of the Laws, 37 CarIf. L. Rev. 341, 348, 351 (1949).

114381 U.S. at $450,455-56$.

115 Id. at $456-57$.

116 Id. at 458.

117 Id. at 458-61; see text accompanying note 24 supra.

118381 U.S. at $464-65$.

110 Justice White particularly mentions $\S 32$ of the Banking Act of 1933, 48 Stat. 194, 12 U.S.C. $\$ 78$ (1964). 381 U.S. at $466-67$. That section prohibits a partner or employee of a security underwriting firm from being a director of a national bank. It was held constitutional in Board of Governors v. Agnew, 329 U.S. 441 (1947), and the government's argument in Brown urged the analogy between $\$ 504$ and $\S 32$.

120 Notes 60-61 supra and accompanying text. 
places these statutes on shaky constitutional grounds. Such a result he calls "perverse"121 and attributes to two major flaws in the majority's reasoning.

The basic flaw is that the majority, in discussing the specificity element of bill of attainder in terms of overinclusiveness and underinclusiveness, used equal protection language ${ }^{122}$ while ignoring the Court's well-developed equal protection doctrine.

[T]his Court has long recognized in equal protection cases that a legislature may prefer to deal with only part of an evil .... And it is equally true that a group may be singled out for regulation without any punitive purpose even when not all members of the group would be likely to engage in the feared conduct. ${ }^{123}$

The majority's per se approach-that is, invalidating a statute because it is both overinclusive and underinclusive-is inconsistent, White feels, with the Court's normal approach to equal protection problems. White would give credence to the legislative judgment that practices of certain groups require regulation in the public interest. ${ }^{124}$

The second inajor flaw is the majority's reading of a punitive rather than regulatory purpose into section 504 . White concedes that a legislative sanction unaccompanied by any legitimate legislative purpose may properly be called punitive. He also concedes that legislative history can be used to determine whether the purpose of the deprivation is punitive or regulatory. But White finds the deprivation imposed by section 504 is connected with a legitimate legislative purpose-to prevent political strikes-and he finds no punitive intent in his reading of legislative history. As a result, White finds section 504 lacking the element of punishment that is essential to a finding of bill of attainder. ${ }^{125}$

The Brown decision, by expressly returning to the principles of the Cummings, Garland, and Lovett holdings and adopting a broad view of what constitutes punishment, injects new vitality into the Court's bill of attainder doctrine. But the basic weakness of Brown is that it did no more than iterate the pre-1950 decisions while leaving the procedural due process suggestion of Lovett ${ }^{126}$ unstated and undeveloped. The pre1950 decisions had been easily distinguished in the 1950's by a Court not

121381 U.S. at 472 .

122 Note 113 supra and accompanying text.

123381 U.S. at 474 .

$124 I d$. at 475 . White here seems to ignore the fact that $\$ 504$, by its very wording, is not aimed at any practices of the Commumist Party, but at the members of that party. The statute, in effect, sets up an irrebuttable presumption that party members engage in certain practices.

125 Id. at 475 .

120 See note 66 supra and accompanying text. 
anxious to invoke the bill of attainder protection. There is no assurance the Court will not find Brown as easy to distinguish in the future, leaving the decision "more of a tour de force than a potent threat to deprivative, or even discriminatory, legislation," as one commentator described the Lovett decision. ${ }^{127}$

The majority in Brozen also injected a potential new source of confusion in the bill of attainder doctrine. By unnecessarily framing its specificity analysis in equal protection terms, the majority has invited the Court to apply equal protection doctrine to bill of attainder challenges in the future. And, as will be demonstrated later, equal protection doctrine is irrelevant to and actually undermines a meaningful and effective bill of attainder doctrine. ${ }^{128}$

\section{III}

The Court's ANalyticaI. Approach

\section{A. The Division on the Court}

The weakness of the Court's bill of attainder doctrine is reflected in the sharp division of the Court in those decisions in which a statute has been held unconstitutional as a bill of attainder. Only Lovett has attracted more than a bare majority of the Court, and the Lovett majority of six justices can best be explained by the very boldness of Congress in legislating against three nained individuals. ${ }^{120}$ The split in the Court suggests an uneasiness and dissatisfaction with the two opposing views of bills of attainder which have emerged in the past two decades.

The narrow view, emphasizing the form of the legislative enactment, had its most complete expression in Justice Frankfurter's concurring opinion in Lovett. ${ }^{130}$ Frankfurther readily recognized the criticism that would fall on his narrow historical test and its mechanical application:

It may be said that such a view of a bill of attainder offers Congress too easy a mode of evading the prohibition of the Constitution. Congress need merely omit its ground of condemnation and legislate the penalty! But the prohibition against a "Bill of Attainder" is only one of the safeguards of biberty in the arsenal of the Constitution. There are other provisions in the Constitution, specific and comprehensive, effectively desigued to assure the liberties of our citizens..$^{131}$

This candor night well disarm a critic. But, assuming the bill of attainder prohibition was aimed at evils which can still be found in legislation,

127 Davis, United States v. Lovett and the Attainder Bogey in Modern Legislation, 1950 WASE. U.L.Q. 13, 45.

128 See text accompanying notes 136-46 infra.

129 See Davis, supra note 127, at 44-45.

130 Text accompanying notes $70-76$ supra.

131 Urited States v. Lovett, 328 U.S. 303, 326 (1946). 
it offers an unconvincing explanation for allowing legislative sophistication to make that prohibition an anachronism. ${ }^{132}$ Justice Field anticipated the Frankfurter argument in Cummings and answered it convincingly. "The Constitution deals with substance, not shadows . . .," he wrote. "If the inhibition can be evaded by the form of the enactment, its insertion in the fundamental law was a vain and futile proceeding."133 The narrow view expounded by Frankfurter has not yet been embraced in its entirety by the Court; but its emphasis on the form of the legislation is reflected in many of the post-Lovett decisions, particularly in the highly technical approach to the punishment requirement of a bill of attainder.

The broad view also has its weaknesses. While it tends to emphasize the evils rather than the form of bills of attainder, it occasionally paints the attainder prohibition with too broad a stroke. Justice Black, for example, would extend the proscriptions of the bill of attainder clause to the executive branch under a "pseudo-bill of attainder" concept. . $^{134}$ The fact that the Constitution prohibits bills of attainder and that the prohibition is contained in that section of the Constitution which places specific restrictions on congressional action seems clearly to refute any pseudo-bill of attainder concept. The effect of such efforts to invoke the bill of attainder clause where it is not applicable is to obscure even further the meaning of that constitutional protection.

The proponents of the narrow and broad views of bills of attainder share a common weakness. As the Brown decision illustrates, the proponents of both viewpoints would define a bill of attainder as a legislative act which inflicts punishinent on named individuals or members of an easily ascertainable group without judicial trial. ${ }^{135}$ But then the meaning of each of the three elements in the definition is analyzed in isolation without relating the three elements to each other. As a result of this analytical approach, legal concepts which have been developed outside of the bill of attainder context and which are irrelevant to the bill of attainder prohibition have crept into various bill of attainder decisions. This, in turn, has distorted the meaning of the bill of attainder proscription.

132 Those other "safeguards of liberty in the arsenal of the Constitution" proved totally ineffective as weapons against the legislation challenged in bill of attainder cases decided between Lovett and Brown. In none of those cases was the legislation struck down on constitutional grounds. See cases cited note 90 supra.

133 Cummings v. Missouri, 71 U.S. (4 Wall.) 277, 325 (1867). (Emphasis added.)

134 See Joint Anti-Fascist Refugee Comm. v. McGrath, 341 U.S. 123, 143-44 (1951) (concurring opinion).

135 United States v. Brown, 381 U.S. 437, 448-49, 462 (1965). 


\section{B. The Specificity Element}

The bill of attainder clause prohibits Congress from focusing on the specific individual or individuals who will be subject to the sanctions of a statute. In this sense, the bill of attainder clause is part of the constitutional scheme which seeks to confine Congress to a general rulemaking function. "It is the peculiar province of the legislature, to prescribe general rules for the government of society; the application of those rules to individuals in society would seem to be the duty of other departments."136 A hiteral application of this principle would restrict Congress to passing only those statutes which apply generally to all persons in society. The Court has not placed such a restriction on Congress, or the state legislatures. The Court has recognized that legislative bodies, in tackling a problem, "may take one step at a time, addressing itself to one phase of the problem which seeins most acute to the legislative mind."137 The Court has developed the doctrine of reasonable classification to accommodate the apparent conflict between the constitutional command that a legislature confine itself to general rule making and the practical considerations that force a legislature to meet specific problems and abuses with more narrowly drawn legislation. ${ }^{138}$

The doctrine of reasonable classification has been developed and refined not in bill of attainder cases but in cases in which statutes have been attacked as denying equal protection of the law. As a result, that doctrine involves considerations which are not relevant to the specificity which is prohibited by the bill of attainder clause. For example, a legislative classification will generally be sustained as "reasonable" if it bears a rational relationship to a legitimate legislative purpose. ${ }^{130}$ The specificity barred by the bill of attainder clause admits to no sucl test of reasonableness. That clause flatly denies Congress the power to designate the particular individuals who will be subject to the sanctions of a statute.

136 Fletcher v. Peck, 10 U.S. (6 Cranch) 87, 136 (1810).

${ }^{137}$ Williamson v. Lee Optical, Inc., 348 U.S. 483,489 (1955). See also Semler v. Oregon State Bd. of Dental Examiners, 294 U.S. 608, 610 (1935).

138 See Tussman \& tenBroek, supra note 113, at 343-44. The doctrine of reasonable classification has been developed in cases challenging state statutes as denials of equal protection of the law. The absence of any equal protection clause, as such, in the Bill of Rights has generally meant a due process attack on similar acts of Congress as being "arbitrary, capricious and unreasonable." See, e.g., Nebbia v. New York, 291 U.S. 502, 525 (1934); Lapides v. Clark, 176 F.2d 619, 620 (D.C. Cir. 1949), cert. denied, 338 U.S. 860 (1949). But the Court's incorporation of equal protection notions in the due process clause of the fifth amendment, see Bolling v. Sharpe, 347 U.S. 497 (1954), and Schneider v. Rusk, 377 U.S. 163 (1964), would clearly suggest that the doctrine of reasonable classification, as such, is equally applicable to acts of Congress.

139 See, e.g., the concurring opinions of Justice Frankfurter and Justice Jackson in American Communications Ass'n v. Douds, 339 U.S. 382 (1950). 
Therefore, if the bill of attaimder doctrine is to have meaning and vitality independent of the equal protection doctrine implicit in the reasonable classification concept, the problems of legislative classification must be distmguished from the specificity element of bills of attainder.

Specificity in its classic sense is present in a statute when the legislature has identified by name the person or persons who will be subject to the statute's sanctions. The Court, however, has properly recoguized in its attaimder definition and in its decisions that specificity of this nature is not essential to a bill of attainder. The required specificity is also present when a statute imposes its deprivations on members of an easily ascertainable group. It is when statutory identification of this nature is involved, however, that specificity can be confused with classification. One distinction between classification and specificity is immediately apparent. In many classification problems, the class is created by the statute and has no meaningful significance or existence as a class or identifiable group outside the context of the particular statute. Thus, should Congress make it illegal to leave the country to evade the draft, it would create a class of persons-those who are eligible for the draft and would leave the country for the illegal purpose-who would have no identity as a class but for the statute. A bill of attamder, on the other hand, inflicts its punishment on a class of persons who have group identity independent of the particular statute, as did the Communist Party members who were barred from union office by the statute invalidated in Brozen.

This difference alone, however, will not serve to distinguisl specificity from classification in all instances, since a number of equal protection cases involve classifications of persons who have group identity independent of the challenged statute..$^{140}$ The chief objection to the use of the doctrine of reasonable classification to define bill of attainder specificity is the standard of reasonableness that would be applied. A further distinction between classification and specificity can be drawn, therefore, according to those statutes of himited apphicability in which the standard of reasonableness is not tolerable. History suggests the basis on which this distinction can be made.

Bills of attainder in England were frequently products of political turmoil and unrest. ${ }^{141}$ Their victims were usually individuals who posed a threat to the security of the crown or to the established pohitical

140 See, e.g., Morey v. Doud, 354 U.S. 457 (1957) (firms issuing money orders); Williamson v. Lee Optical, Inc., 348 U.S. 483 (1955) (opticians); Daniel v. Family Security Life Ins. Co., 336 U.S. 220 (1949) (insurance companies and their employees).

1412 Story, Comomentaries on the Constitution of the UnIted States 239-40 (3rd ed. 1858). 
alliances in Parliament. ${ }^{142}$ English acts of attainder which identified their victims on some basis other than name generally did this by describing the adherence of the attainted to a person or persons engaged in activities deemed treasonable. ${ }^{143}$ This suggests that the specificity barred by the bill of attainder clause is identification in a statute of individuals because of their membership in groups or association with other individuals engaged in unpopular political activities.

This standard of specificity would be consistent with our constitutional system and with past opinions of the Supreme Court. It would place the same rigid restrictions on legislative action in the sensitive areas of speech and association as are contained in the first amendment. It would involve the same standard of specificity found in those cases in which the Court has invalidated legislation as bills of attainder, covering the rebel sympathizers affected by the test oaths in Cummings and Garland, the naned government employees in Lovett, and the Communist Party members in Brown. And it would leave the doctrine of reasonable classification undisturbed for those cases in which it is clearly applicable. That doctrine has been developed, for the most part, in cases involving legislative regulation of economic activities. ${ }^{14.4}$ Since such statutes involve broad questions of public policy which the legislature is most competent to deal with, the standard of reasonableness in the classification doctrine is an appropriate restraint on judicial interference with the legislative judgment. The prohibitory language of the first amendment, however, suggests the legislature is not to be given the same freedom of action in regulating speecli and association. The Court has recognized this in its equal protection decisions, applying a different and stricter standard when personal liberties rather than purely economic activity is involved. ${ }^{145}$

A statute will have the prohibited specificity when the individuals who will be subject to its sanctions are identified by name, or by their association with named organizations or with other groups or individuals engaged in unpopular political activities. ${ }^{148} \mathrm{~A}$ finding of specificity in

142 See, e.g., the acts of attainder cited in notes 21,23 supre.

143 See, e.g., the Attainder of the Earl of Kildare, 26 Hen. 8, c. 25 (1534) ("all such persons which be or hereafter have been comforters abettors partakers confederates unto said Earl ....").

144 See Tussman \& tenBroek, supra note 113, at 370 .

145 See Comment, 53 CaLIF. L. Rev. 1378, 1409-18 (1965); cf. Korematsu v. United States, 323 U.S. 214 (1944); Hirabayashi v. United States, 320 U.S. 81, 95 (1943).

148 Except where specificity is achieved by identifying the statute's victims by name or by affiliation with a named organization, defining specificity as suggested necessarily limits the application of the bill of attainder clause to legislation which curtails the rights of unpopular political groups and their members. The fact that bills of attainder were used primarily for such purposes in England and in the colonies suggests that such a limitation 
this sense will not, however, lead automatically to the conclusion that a particular statute is a bill of attainder. For a bill of attainder imposes its punishment on specific persons without judicial trial. Thus, if Congress made it illegal for a pacifist to leave the country for the purpose of evading the draft but left it to the courts to determine whether such a purpose was present in each case, the statute would have bill of attainder specificity but would not be a bill of attainder. ${ }^{147}$ But if such a statute imposed its sanctions automatically or without meaningful judicial intervention, ${ }^{148}$ it would fall precisely within the attainder prohibition. ${ }^{149}$ This emphasizes that the separate elements of a bill of attainder cannot be considered apart from the context of the total definition if an effective attainder doctrine is to be developed.

The specificity element caused few problems in the Supreme Court's search for a bill of attainder doctrine prior to Brown. But the majority's discussion of that element in terms of underinclusiveness and overinclusiveness, the classic terminology of legislative classification, has invited the Court in the future to apply the doctrine of reasonable classification to bill of attainder cases. In fact, the Brown dissent argued that the classification according to Communist Party membership fell within the bounds of reasonableness. The English experience suggests emphatically, however, that such statutory designations are never reasonable and are flatly prohibited by the bill of attainder clause.

would not be inconsistent with the purposes of the bill of attainder prohibition. It was noted earkier that history provides few clues to the reasons for inserting the attainder prohibition in the Constitution. See text accompanying notes 27-38 supra. However, it can be assumed that the framers of the Constitution were well aware of the purposes for which bills of attainder were normally used and that they were seeking to prevent such abuses of legislative power through the attainder prohibition. The suggested limitation would make the attainder prohibition unavailable as a challenge to statutes involving economic regulation. But the doctrine of reasonable classification seems adequate as a legislative check in that area. As was noted above, that doctrine recognizes the deference the courts allow the legislature in deciding those broad questions of public policy. See text accompanying note 144 supra.

147 Of course, such a statute would raise other constitutional problems, particularly an issue of unreasonable classification, and Justice Frankfurter's admomition that there are other weapons in the arsenal of the Constitution to deal with such problems is clearly applicable. See text accompanying note 131 supra.

${ }^{148}$ See text accompanying notes 205-06 infra for a discussion of the concept of meaningful judicial intervention in the bill of attainder context.

149 See, e.g., Kennedy v. Mendoza-Martinez, 372 U.S. 144 (1963), where the Court held unconstitutional a law which stripped an individual of his citizenship if he left the country in time of national emergency to evade military service. The act was invalidated because the sanction was imposed automatically "without affording the procedural safeguards guaranteed by the Fifth and Sixth Amendments." Id. at 166. The decision did not rest on the bill of attainder prohibition because there was no element of specificity in the statute. But, had such specificity been present, the case would clearly have been one for application of the bill of attainder doctrine. 


\section{. C. The Punishment Element}

The punishment element has been the most fertile source of confusion in bill of attainder cases. Wrenching this element from the context of the total bill of attainder definition does the greatest violence to the Court's attainder doctrine.

To be brought within the bill of attainder category a statute must contain a sanction of some sort, because it is the punitive element that distinguishes bills of attainder from private bills for the benefit of specific persons which a legislature may properly pass. ${ }^{150}$ But the very. use of the word "punishment" in the definition of bill of attainder is itself a source of confusion. The definition of punishment developed by the Court for one purpose can be totally irrelevant for purposes of a bill of attainder analysis. For example, the quality of punishment that must be shown to support an eighth amendment contention of "cruel and unusual punishment" is not necessary for a bill of attainder. Yet the very label "punishment" seems to lead the Court automatically to definitions of punishment developed in cases wholly unrelated to bills of attainder. ${ }^{151}$ In this respect, Chief Justice Warren's observation in Trop v. Dulles is pertinent: "How simple would be the tasks of constitutional adjudications and of law generally if specific problems could be solved by inspection of the labels pasted on them." 1162

An examination of the post-Lovett cases reveals at least four distinctions that have been made to support a finding of no punishment.

\section{Right Versus Privilege}

A number of state bill of attainder decisions distinguish between the denial of a right and the denial of a privilege, calling only the former "punishment."153 Such a distinction was firmly rejected in Cummings, where the Court found the test oath was based on the assumption that those sympathetic to the Confederacy deserved punishment and the only

1602 WOOdDESON, VINERIAN Lectures 623 (1792).

151 See, e.g., Justice White's dissent in United States v. Brown, 381 U.S. 437, 476 (1965), where he applies the criteria for determining if a punitive elenent is present as set forth in Kennedy v. Mendoza-Martinez, 372 U.S. 144, 168-69 (1963). Significantly, the Kennedy opinion, after listing those criteria, does not apply them. Id. at 169.

152356 U.S. 86, 94 (1958).

153 Cf., e.g., Murphy and Glover Test Oath Cases, 41 Mo. 339 (1867); State v. Heighland, 41 Mo. 388 (1867); Blair v. Ridgely, 41 Mo. 63 (1867); Woodgate v. Woodson, 41 Mo. 227 (1867). All four cases involved deprivations imposed by the same test oath invalidated in Cummings. The court found punishnent in the Murphy and Heighland cases because the deprivation involved the "right" to pursue a private profession. No punishnient was found in Blair and Woodgate because the deprivation was of the "privilege" of voting and of holding public office. But see Sherbert v. Verner, 374 U.S. 398, 404-05 (1963), for a rejection of the "privilege" notion. 
effective punishment was to deprive them "of some of the rights and privileges of the citizen."154 This position was reaffirmed in Lovett where the Court found the "permanent proscription from any opportunity to serve the government is punishment and of a most severe type..1155

A suggestion of the right-privilege distinction crept into two subsequent cases. The Court in Douds said it was not free to treat the denial of access by unions to the National Labor Relations Board "as if it merely withdraws a privilege."158 The implication is that if the deprivation could be labeled the denial of a privilege there would have been no finding of punishment. In Flemming, the Court nearly embraced the right-privilege notion by calling the termination of Social Security benefits "the niere denial of a noncontractual governmental benefit." conclusion followed from the Court's ruling that the respondent had no vested right in the benefits. Therefore, their termination did not anıunt to punishment.

\section{Qualification Versus Punishment}

In the Garner decision, the Court found that the loyalty oath requirement was an exercise of the legislature's right to set qualifications for public employment and did not constitute punishment. ${ }^{158}$ The Court noted the loyalty oath requirement was of general applicability and relied on Garland for the proposition that the legislature "may undoubtedly ... prescribe qualifications for the pursuit of any of the ordinary avocations of life."159 The Court, however, had apparently forgotten the admonition of $C$ ummings that the qualifications prescribed for a profession or public office will be nonpunitive only if they bear a reasonable relationship to a person's fitness for the particular profession or public office. ${ }^{160}$ The loyalty oath in Garner was aimed at keeping the disloyal from city employment, yet the Court did not consider whether the loyalty oath's broad applicability might act as punishment for at least some applicants for city positions. It is one thing to find that disloyalty would be a proper basis for disqualifying an individual who

154 Cummings v. Missouri, 71 U.S. (4 Wall.) at 320. (Emphasis added.)

155328 U.S. at 316.

156339 U.S. at 390.

157363 U.S. at $61 \%$.

158 Garner v. Board of Pub. Works of Los Angeles, 341 U.S. 716 (1951).

150 Id. at 722.

16071 U.S. (4 Wall.) at 319. It was the "reasonable relationship" test that led the Court to distinguish Cummings in Dent v. West Virginia, 129 U.S. 114, 125 (1889), and Hawker v. New York, 170 U.S. 189, 198 (1898). See notes 58-61 supra and accompanying text. It should be noted the reasonableness test is injected at this point, not as a valid general test for bills of attainder, but as a means of suggesting that the label "qualification" does not preclude a finding of punishment in a bill of attainder context. 
would have supervision of the city's water system. Such a position offers the disloyal person a clear opportunity to translate his disloyalty into action which would peril the state. It is quite another thing to make disloyalty a basis for disqualifying an applicant for trash collector. In such a case, it would be difficult to conceive of any reasonable relationship between loyalty and fitness for the particular job. And this, in turn, would make the disqualification from city employment "punishment" of the same quality found in Cummings.

\section{The Post Facto Requirement}

Justice Frankfurter argued in Lovett that the only punishment appropriate to a bill of attainder analysis was punishment for past acts. ${ }^{101}$ It was largely on this basis that the Court found no element of punishment in the oath upheld in Douds. ${ }^{162}$ Frankfurter's insistence that bill of attainder punishment be post facto in operation stemmed from the historic link he found between bills of attainder and ex post facto laws:

Frequently a bill of attainder was ... doubly objectionable because of its ex post facto features. This is the historic explanation for uniting the two mischiefs in one clause- "No Bill of Attainder or ex post facto Law shall be passed." ... [I]f it [the statute] is not an ex post facto law, the reasons that establish that it is not are persuasive that it cannot be a bill of attainder. ${ }^{163}$

It is true that English bills of attainder "frequently" contained ex post facto elements, particularly when they imposed punishment for acts not punishable when committed or imposed punishment greater than prescribed by existing law. ${ }^{164}$ But not all English bills of attainder were of this nature. Conditional attainders imposed punishment only if the attainted failed to perform some act in the future, and that future act generally was to surrender himself for trial by a certain day. ${ }^{105}$ Thus, Frankfurter's insistence on post facto punishment is rebutted by the same reference to history that he uses to support his position.

101 "Punishment presupposes an offense, not necessarily an act previously declared criminal, but an act for which retribution is exacted." 328 U.S. at 324.

162339 U.S. at 413-14.

163 United States v. Lovett, 328 U.S. 303, 323 (1946).

164 See Calder v. Bull, 3 U.S. (3 Dall.) 386, 389-90 (1798).

165 See, e.g., 17 Car. 2, c. 5 (1665). ("Act for Attaining Thomas Dolman, Joseph Bampfield and Thomas Scott of High Treason if they render not themselves by a day.") See also 9 HeNtng's Statutes at LaRge of Virginfa 463-64 (1821) ("An act to attaint Josiah Philips and others, unless they render themselves to justice within a certain time.") (Statute enacted in 1778). For the background to the attainder of Josiah Philips, see 1 Watson, TrE ConSTITUTION OF THE UNITED STATES 735 n.40 (1910). The statute upheld in Douds was a modern example of a conditional attainder. If a union's officers did not comply with the affidavit requirement within a certain period, the statute deprived the union of access to the National Labor Relations Board. 


\section{Traditional Notions of Punishment}

Justice White's dissent in Brown suggests that one of the tests to be applied to determine if a statute cliallenged as a bill of attainder imposes a deprivation that can be called punishment is "whether it has historically been regarded as a punishment."166 This argument is open to the same criticism as Justice Frankfurter's insistence that a statute must contain a declaration of guilt to constitute a bill of attainder. Congress need only devise some unique punishment or deprivation, and the Court will be precluded from finding a bill of attainder.

The traditional notions of punishment cause the greatest difficulty in deportation cases. In Flemming, the Court suggested that a statute which would in all other respects amount to a bill of attainder could survive such a constitutional challenge if its only "punishment" was the deportation of an alien. "[D] eportation has been held to be not punishment," said the Court, ${ }^{167}$ relying primarily on Fong Yue Ting v. United States. ${ }^{168}$ That decision drew a distinction between the banishment of a citizen and the deportation of an alien, terming the former punishment but the latter sinply an exercise of the plenary power of Congress to admit aliens and control their right to remain in the country. More recent cases have cast some doubt on the validity of that distinction. In Galvan v. Press, ${ }^{169}$ the Court said "the intrinsic consequences of deportation are ... close to punishment for crime ...."170 The strained efforts to draw the banishment-deportation distinction often appears to be a matter of quibbling over labels. That distinction has validity when applied to an alien seaman who jumps ship at an American port, is caught within a few days, and is ordered to leave the country immediately. It starts to lose its validity when applied, as it was in Flemming, to an alien who had made his home in the Umited States for more than forty years and was forced at the age of sixty-five to return to Yugoslavia, which was truly a "foreigu" country to him. In such cases, where bill of attainder is clearly an issue, the Court should discard its own traditional notions of punishment and look instead at the forms of punishment historically associated with bills of attainder. The Court would find that banishment and exile were among the common penalties imposed by such acts in England and the colonies. ${ }^{171}$

160381 U.S. at 476 (quoting Kennedy v. Mendoza-Martinez, 372 U.S. 144, 168-69 (1963)).

107363 U.S. at 616; cf. Sherman v. Imnrigration \& Naturalization Serv., 350 F.2d 894, 898-

99 (1965) (dicta), rev'd on rehearing en banc, 34 U.S.L. WeEk 2393 (2d Cir., Jan. 17, 1966).

168149 U.S. 698 (1893).

169347 U.S. 522 (1954).

170 Id. at 531. See also Fong Haw Tan v. Phelan, 333 U.S. 6, 10 (1948).

171 See, e.g., 19 \& 20 Car. 2, c. 2 (1667); 9 Geo. 1, c. 17 (1723). See also Var TrNe, 
These efforts of the Court to find some label other than punishment for a statutory deprivation seems to be based on the assumption that a finding of punishment would make the challenged statute a bill of attainder, even in the absence of the other elements. Such an assumption is wrong. Otherwise, every criminal statute would be a bill of attainder. The confusion that surrounds the Court's punishment analysis seems to be primarily a problem of misplaced emphasis. The bill of attainder prohibition is aimed not so much at the presence of punishment in a particular statute but at how the punishment is imposed by the statute. Therefore, a punitive statute will not be a bill of attainder unless the punishment is imposed with the prohibited specificity and without judicial trial.

Viewed in this manner, the Court's confusion in its punishment analysis is often a problem of semantics. While labels alone will not solve complex constitutional problems, the very label "punishment" seems to be a formidable barrier to the Court's development of a meaningful bill of attainder doctrine. The proper approach is to determine whether the challenged statute imposes a deprivation typically associated with bills of attainder. These include exclusion from a job or profession, banishment, and confiscation of property. When such a deprivation is present, the punishment element of bill of attainder is satisfied. The inquiry is then whether the deprivation is imposed with the prohibited specificity without judicial trial.

\section{The Judicial Trial Element}

The judicial trial requirement has been accurately characterized as the "forgotten eleinent" in the Court's bill of attainder doctrine. ${ }^{172}$ The Court accepts the proposition that a bill of attainder is a statute which imposes its punishment with the forbidden specificity and without judicial trial. But, except for the Lovett decision, ${ }^{173}$ there is very little discussion in the cases of the significance of the words "without judicial trial" in the total bill of attainder definition. This omission has hindered the development of a meaningful bill of attamder doctrine.

The significance of the judicial trial element is discussed at length below. It is sufficient to note at this point that this element requires that the courts and not the legislature inust determine on whom the sanctions of a statute should fall. The legislature is prohibited from foreclosing all judicial intervention and from shutting off meaningful judicial inquiry

THE Loyautsts in tre AMrerican Revolution 331-33 (1902), for a compilation of the colonial bills of attainder imposing the punishment of banishment and exile.

172 Comment, 63 YaIE L.J. 844, 857 (1954).

173328 U.S. at $317-18$. 
into statutory coverage. This element can explain the result in Hawker v. New York ${ }^{174}$ although the Court did not give such an explanation. The challenged statute, which barred persons convicted of felonies from the practice of medicine, contained a deprivation appropriate to a bill of attaimder. And, arguably, the deprivation was imposed on members of an easily ascertainable class (convicted felons). ${ }^{175}$ But the determination of those subject to the deprivation was made by a court at the time an individual was convicted of a felony. The petitioner in Hawker had a colorable ex post facto complaint. But the fact that a prior judicial determination had brought the petitioner within the statute's purview defeated his bill of attainder argument.

The statute held unconstitutional as a bill of attainder in Brown imposed its deprivations not only on members of the Communist Party but also on persons convicted of certain felonies. ${ }^{176}$ The portion of section 504 that applied to convicted felons was held not to be a bill of attainder in Postma v. International Bhd. of Teamsters. ${ }^{177}$ The analysis suggested above for the Hawker decision supports the holding in Postma.

\section{IV}

\section{A PROPOSAL FOR A MORE MEANINGFUL BILL OF ATTAINDER DOCTRINE}

\section{A. A Suggested Restatement}

Perhaps the inajor weakness of the Supreme Court's bill of attainder doctrine is its failure to focus on the evils inherent in bills of attainder. This weakness can be traced to the Court's failure to examine closely the Englisl experience, whicl suggests that the basic evil of bills of attainder is that they impose a deprivation against a sufficiently specific person without the procedural safeguards afforded at a judicial trial. The Court has recognized that bills of attainder, because they constitute legislative usurpations of judicial power, are foreign to the separation of powers embodied in the Constitution. No such objection can be made, lowever, to the enactment of bills of attainder by Parliament. Not only is there

174170 U.S. 189 (1898).

175 The existence of the prohibited specificity in the Hawker statute is accepted only arguendo, since the classification of convicted felons does not conform to bill of attainder specificity as defined in this Comment.

170 See note 102 supra.

177337 F.2d 609 (2d Cir. 1964). The court rejected the bill of attainder argument by citing DeVeau v. Braisted, 363 U.S. 144 (1960). In DeVeau, joint New York and New Jersey legislation barred from union office convicted felons. The petitioner had been convicted of grand larceny in 1920 and was suspended from his union post following passage of the act. Justice Frankfurter said the statute was not a bill of attainder because it "enlbodies no further implications of appellant's guilt than are contained in his 1920 judicial conviction ...." Id. at 160 . 
no separation of powers scheme in the British system of government, but Parliament is the seat of supreme judicial, as well as legislative, power. ${ }^{178}$ Parliament still retains the power to enact bills of attainder, although such enactments have fallen into total disuse in the past 145 years. Therefore, a look at the English experience with and rejection of bills of attainder will provide more insiglt into the evils of such legislation than can be gained froin viewing them solely in the context of a separation of powers system.

The Magna Carta gnaranteed to all Enghishmen the riglit of a trial by his peers. ${ }^{179}$ During the thirteenth and fourteenth centuries, the House of Lords acquired jurisdiction in treason, felony, and impeachment cases involving lords of the realm. ${ }^{180}$ Most English acts of attainder prescribed punishment for activities for which Parliament could have held formal treason trials or impeachment proceedings. ${ }^{181}$ The bill of attainder was simply a more expedient method of dealing with the individual who laad run afoul of the law or Parliament. For example, the person may liave engaged in activity whicl was treasonable, but certain elements of proof were lacking to assure conviction at a formal trial. ${ }^{182}$ Or the king may liave found one of lis ministers becoming too powerful for coinfort but lacked any legal basis to urge impeachment proceedings in Parliament. ${ }^{183}$ In both instances, a bill of attainder would be a convenient alternative to a formal trial and a surer inethod of inflicting punishment.

Althougl acts of attainder were essentially judicial in nature, they were in the form of statutes and their enactment was viewed as an exercise of legislative power. ${ }^{184}$ Therefore, Parliament was under no compulsion to observe the formal procedures of a trial in considering an act of attainder. Parliament might, at its discretion, pernit the subject of the bill of attainder to be represented by counsel and present evidence. ${ }^{185}$ More frequently, however, the consideration of a bill of attainder took the form of normal debate on pending legislation. ${ }^{188}$ Eventually it was

1789 HaIsburx, The Laws of Engrand 19-24 (1909).

179 For a modern critique of the legal efficacy of the Magna Carta, see generally Radin, The Myth of Magna Carta, 60 HARv. I. REv. 1060 (1947).

189 "It was in Parliament peculiarly that the nobility met its peers, and consequently it was natural that the Lords should acquire jurisdiction in such trials." POTTER, AN HistorucaI INTRODUCTION to ENGLisH LAW AND ITS INSTITUTTONS 158-59 (1932).

${ }^{181}$ See Chafee, Three Hunan Rights in the Constitution or 1787, at 99-141 (1956).

182 E.g., the account of the attainder of Sir John Fenwick, id. at 133-35.

188 See ChAFEE, op. cit. supra note 181, at 103.

184 Matiland, The Constrtutional History of England 215 (1913).

${ }^{185}$ See Cooley, The Generat Princtiles of Constitutional Law in the Untred States of America 311 (McLaughlin ed. 1898).

186 Macaulay described the atmosphere in Parbiament while the attainder of Sir Joln Fenwick was being debated: "The arbiters of the prisoner's fate came in and went out as they chose. They heard a fragment here and there of what was said against him, and a frag- 
because bills of attainder did so subvert the regular judicial process that they came under heavy criticism and fell into disuse. ${ }^{187}$

Perhaps the most incisive criticism of Enghish acts of attainder was delivered by Professor Wooddeson. ${ }^{188} \mathrm{He}$ was particularly appalled at the attainder of Sir John Fenwick. ${ }^{189}$ An English statute required the testimony of two witnesses under oath in open court for a conviction of treason. Fenwick had managed to bribe one of the only two witnesses to his part in the attempted assassination of King William III, and he felt confident of escaping punisliment for treason until Parliament resorted to a bill of attainder. ${ }^{190}$ Wooddeson found that:

this proceeding deviated from the rules which govern inferior tribunals. Such variance ... was made by admitting the testimony of a single witness, not upon oath, by allowing written evidence not competent in ordinary trials, and by hearing proof of what had been sworn, where sir John Fenwick was not a party, nor present, and of things transacted by his wife, which could not legally exculpate or convict her husband. ${ }^{191}$

These procedural abuses listed by Wooddeson clearly indicate that the basic evil of bills of attainder were their denial of procedural due process to the accused.

Professor Cooley niade a similar procedural due process critique of bills of attainder, ${ }^{192}$ and the Cummings decision hints at such an argument. The Cummings Court, after citing several specific English acts of attainder, said: "In all these cases there would be the legislative enactment creating the deprivation without any of the ordinary forms and guards provided for the security of the citizen in the administration of justice by established tribunals." 193 The Court did not, however, pursue this line of argument in the opimion.

ment here and there of what was said in his favour. During the progress of the bill they were exposed to every species of influence. One member was threatened by the electors of his borough with the loss of his seat.... In the debates arts were practised and passions excited which are unknown to well constituted tribunals, but from which no great popular assembly divided into parties ever was or ever will be free. The rhetoric of one orator called forth loud cries of 'Hear him.' Another was coughed and scraped down. A third spoke against time in order that his friends who were supping might come in to divide. If the bife of the most worthless man could be sported with thus, was the life of the most virtuous man secure?" 5 Macaulay, History of ENGLAND 198 (1886).

187 CEAFEe, op. cit. supra note 181, at 135-37.

1882 WOODDESON, VINERIAN Lectures, No. 41 (1792).

1898 Will. 3 , c. 4 (1696).

190 See CrafEe, op. cit. supra note 187, at 133-35.

1912 WOODDESON, op. cit. supra note 188 , at 636 .

192 Professor Cooley wrote: "It was quite possible .... for the bill [of attainder] to go through all its stages without the accused party being allowed any opportunity whatever for a hearing; and he miglit be denied a hearing at the will of the legislature in all cases." CoOLEY, op. cit. supra note 185 , at 311 .

10371 U.S. (4 Wall.) at 325. 
On the present Court, only Justice Black has urged a procedural due process basis for the bill of attainder doctrine. In his majority opinion in Lovett, Black wrote:

The effect [of the rider] was to inflict punishment without the safeguards of a judicial trial .... Those who wrote our Constitution well knew the danger inherent in special legislative acts which take away the life, liberty, or property of particular nained persons because the legislature thinks them guilty of conduct which deserves purishment .... And even the courts to which this important function was entrusted were commanded to stay their hands until and unless certain tested safeguards were observed. An accused in court must be tried by an impartial jury, has a right to be represented by counsel, he must be clearly informed of the charge against him, . . . he must be confronted by the witnesses against him, he inust not be compelled to incriminate himself, he cannot twice be put in jeopardy for the same offense, and even after conviction no cruel and unusual punishment can be inflicted upon him.194

This portion of the Lovett opinion is the foundation upon which a procedural due process bill of attainder doctrine could have been built. But the Court's subsequent rejection of the Lovett rationale relegated Black's procedural due process argument to dissenting opinions. In Barenblatt v. United States, ${ }^{195}$ in which the Court affirmed the contempt conviction of a witness who refused to answer questions before the House Committee on Un-Aınerican Activities, Black's bill of attainder argument noted, inter alia, that the framers of the Constitution believed that no one should be punished without "all the procedural safeguards they put in the Constitution as essential to a fair trial .... They believed this because not long before worthy men had been deprived of their liberties, and indeed their hes, through parliamentary trials without these safeguards." ${ }^{196}$ And, in Flemming, Black would have held the termination of Social Security benefits unconstitutional as a bill of attamder because the deprivation was imposed "without a trial according to due process of law."197

The Brown opinion is devoid of any discussion of the procedural due process basis for the bill of attainder doctrine, and therein lies the opinion's major weakness. Brown does talk of the bill of attainder clause barring "trial by legislature."198 But this is mentioned only to support the majority's belief that the bill of attainder clause was designed solely to implement the separation of powers doctrine. This line of reasoning

\footnotetext{
194328 U.S. at $316-18$.

195360 U.S. 109 (1959).

$196 \mathrm{Id}$. at 160 .

197363 U.S. at 627 .

198381 U.S. at 442.
} 
has a valid basis, ${ }^{109}$ but it fails to go one step further and inquire into why the legislature should not usurp a judicial function under our system of government. ${ }^{200}$ Justice Black has provided the answer-such usurpations deprive the individual of the procedural safeguards he would be afforded in a court of law.

Certain procedural safeguards would probably be afforded the subject of a bill of attainder in England today should Parliament revive that form of legislative enactment. ${ }^{201}$ These include the right to representation by counsel and to present evidence. ${ }^{202}$ These same safeguards were afforded some of the victims of acts of attainder approved by Parhament in the past, ${ }^{203}$ although it would appear these safeguards were allowed or denied at the discretion of Parhament and were not a matter of right. ${ }^{204}$ Similarly, nothing compels Congress to afford the potential victims of a bill of attainder the procedural safeguards of the fourth, fifth, and sixth amendments while suclı a statute is being prepared and debated. This underscores the importance of placing the bill of attainder doctrine on a procedural due process basis.

If the bill of attaimder prohibition is viewed as a guarantee of procedural due process, the bill of attainder analysis would take this form: When the Court finds that Congress has prescribed punishment with the prohibited specificity, the statute will be invalid unless it contains provisions for meaningful judicial determination that the deprivation should be imposed.

It is essential that the judicial intervention be ineaningful. The Brown case illustrates the significance of this requirement. To the extent that a Communist complied with section 504 and voluntarily surrendered his position of union leadership, he would be punished in a sense appropriate in a bill of attainder context, with a total absence of judicial intervention and a complete denial of the procedural safeguards of a trial. But the Brown case did not arise in this manner. The respondent retained both his union position and Communist Party membership, inviting criminal prosecution. The government accepted the invitation, and it might be argued that this respondent had his day in court with all the procedural

180 But see Justice White's rebuttal of the separation of powers argument in Broven. 381 U.S. at $472-73$.

200 The Court does point out that a large legislative body is not functionally suited to conduct trials. 381 U.S. at $445-46$. But this still misses the crucial point that a person "tried" by a legislative body in a bill of attainder is denied the procedural safeguards of a judicial trial.

201 See 21 Hatsburx, The Laws of Eingtand 727 (1912).

202 Ibid.

203 See, e.g., 13 Howelt, State Triass 554 (1812) (the attainder of Sir John Fenwick); 1 Trial of QueEn Caroltne 16-17 (1820).

204 See note 192 supra. 
safeguards a bill of attaincer denies. Such an argument is more apparent than real.

Even under the old parliamentary acts of attainder there was judicial intervention of a sort. The attainted was taken before a magistrate following his arrest. The attainted, however, was given no opportunity to contest the general issue of his guilt in relation to the offenses specified in the bill of attainder. He was permitted only a challenge on the collateral issue of identification-whether he was the same person named in the bill. Never at any stage of the bill of attainder proceedings was there a judicial determination of the attainted's guilt of the evil for which he was being punished. ${ }^{205}$

This situation was paralleled in Brown. Congress, in enacting section 504 , was seeking to prevent or reduce the likehhood of political strikes that would interrupt the free flow of commerce. The respondent in Brown, however, was never permitted to place in issue at the trial the question of whether he was likely to call a political strike. In other words, he was not allowed to contest the general issue of whether he was guilty of the evil at which the statute was aimed. The trial court, in fact, refused to admit evidence that the executive board of which respondent was a member had never called a strike, political or otherwise. ${ }^{200}$ In effect, the only issue tried was one of identification: Was respondent both a union officer and a member of the Communist Party? Congress, by foreclosing any trial on the general issue of guilt, deprived the respondent of a meaningful judicial determination of whether he should incur the penalties of the statute. Without such a determination, the procedural safeguards which were afforded at the trial were illusory.

Restating the bill of attainder doctrine in terms of a constitutional guarantee of procedural due process would clearly align that doctrine with the lessons of history. And those lessons teach that bills of attainder were acts of expediency employed by legislatures when the procedural safeguards of a judicial trial might frustrate the legislative desire to see certain persons punished.

\section{B. Significance of the Restatement}

Restating the bill of attainder doctrine in terms of procedural due process would do more than make clearer the reasons for the constitutional proscription of those legislative enactments. It would also mean a more meaningful scope of review of statutes challenged as bills of attainder. Where inembers of the Court have considered due process argunents directed at statutes challenged as bills of attainder, they have

205 See 2 Wooddeson, op. cit. supra note 188, at 626-29.

208381 U.S. at 440 n.4. 
tended to apply the "reasonableness" test of substantive due processlooking only to see whether the statute bears a rational relationship to a permissible legislative goal. ${ }^{207}$ The substantive due process test of reasonableness, however, was developed in a constitutional context wholly independent of considerations implicit in the bill of attainder prohibition. The substantive due process standard seeks to define the limits of judicial intrusion into fields of broad public policy in which the legislative judgment is paramount. ${ }^{208}$ The inquiry is totally different where a statute is challenged as a bill of attainder. The basis of sucl a challenge is that the legislature has stepped out of its constitutional bounds and has intruded into an area reserved for the judiciary. The Court need not defer to the legislative judgment concerning the reasonableness of the means chosen by Congress to ineet a particular problem. The thrust of the bill of attainder clause is that Congress is absolutely forbidden to select the means of singhing out particular individuals with the prohibited specificity for statutory sanctions. That clause is a mandate to the Court to examine with care the statutory scheme adopted by Congress to meet a particular evil and to strike down as unconstitutional any statute which imposes its deprivations with the prohibited specificity and without the procedural safeguards afforded at a judicial trial.

This question of scope of review can be significant in future bill of attainder challenges in liglit of the unreasonable classification and equal protection language implicit in the Brown decision's discussion of the specificity element of section $504 .{ }^{209}$ The Court traditionally applies a test of reasonableness to statutes challenged as unreasonable legislative classifications under the fourteenth amendment. ${ }^{210}$ The Court's adoption of a procedural due process rationale would eliminate the formidable barrier that the reasonableness test places in the path of a successful bill of attainder challenge. The true meaning of the bill of attainder clause is that Congress cannot choose such a means of legislating against

207 See, e.g., Justice Frankfurter's statement in Douds: "It must suffice for me to say that the judgment of Congress that trade unions which are guided by officers who are committed by ties of membership to the Communist Party must forego the advantages of the Labor Management Relations Act is reasonably related to the accomplishment of the purposes which Congress constitutionally had a right to pursue." 339 U.S. at 418 (concurring opinion). (Emphasis added.) See also id. at 424 (concurring opinion of Justice Jackson); Flemming v. Nestor, 363 U.S. 603, 617 (1960).

208 See, e.g., Ferguson v. Skrupa, 372 U.S. 726 (1963); Daniel v. Family Security Life Ins. Co., 336 U.S. 220 (1949); Lincohı Fed. Labor Union v. Northwestern Iron \& Metal Co., 335 U.S. 525 (1949); West Coast Hotel Co. v. Parrish, 300 U.S. 379 (1937); Nebbia v. New York, 291 U.S. 502 (1934).

209 Note 113 supra and accompanying text.

210 See, e.g., Ferguson v. Skrupa, 372 U.S. 726 (1963); Morey v. Doud, 354 U.S. 457 (1957); Williamson v. Lee Optical, Inc., 348 U.S. 483 (1955). 
a particular evil, no matter how rational the connection between the means and the end.

\section{A. Suggested Application}

The adoption by the Court of a procedural due process basis for its bill of attainder doctrine could provide a new weapon in the many assaults that have been made on antisubversive legislation which infringes on the rights of free speech and association. One type of such legislation-the "so-called" loyalty oaths-would be particularly affected. Such oaths typically require that the individual subscribing to them disclaim membership in the Communist Party ${ }^{211}$ or in organizations determined to be Communist-fronts or subversive by the Attorney General. ${ }^{212}$ Such oaths have been characterized by Justice Black as follows: "Test oaths are notorious tools of tyranny. When used to shackle the mind they are, or at least they should be, unspeakably odious to a free people. Test oaths are made still more dangerous when combined with bills of attainder which . . . impose pains and penalties for past lawful associations and utterances."213 Despite strong statements such as this and the generally controversial nature of loyalty oaths, the normal constitutional grounds used for challenging such oaths have been only occasionally successful. ${ }^{214}$

The bill of attainder doctrine, however, when restated as suggested in this Comment, would require that loyalty oaths be invalidated when they are based on a disclaimer of membership in designated organizations. Such oaths contain the three elements necessary for a finding of a bill of attainder. The individuals subject to the sanctions of such oaths are identified with the required specificity, since it is only members of politically unpopular organizations who suffer the deprivations prescribed under the oath. The sanction imposed-disqualification from a particular job-is punishment appropriate in a bill of attainder context. And the sanction is imposed automatically, without judicial intervention. The person who cannot truthfully subscribe to the oath is denied employment.

211 This was the nature of the disclaimer the Court held constitutional in American Communications Ass'n v. Douds, 339 U.S. 382 (1950).

212 The oath invalidated in Wieman v. Updegraff, 344 U.S. 183 (1952), was of this nature.

213 Id. at 193.

214 Compare Garner v. Board of Pub. Works of Los Angeles, 341 U.S. 716 (1951) (oath valid; no scienter on the face of the oath, but the Court found scienter implied because of a California Suprene Court decision forty years earher), with Wieman v. Updegraff, 344 U.S. 183 (1952) (oath invalid because no scienter on the face of the oath). More recently, successful challenges to loyalty oaths have been made on grounds that the oaths were void for vagueness. See, e.g., Baggett v. Bullitt, 377 U.S. 360 (1964); Cramp v. Board of Pub. Instruction, 368 U.S. 278 (1961). 
A person who falsely disclaims membership in a designated organization can be prosecuted for perjury. The perjury trial, however, would not provide the individual with the meaningful judicial determination of guilt required by the bill of attainder clause. The court would not be required to determine if the person charged with perjury presented a threat to the security of the state, which is the evil the loyalty oaths seek to guard against. Instead, the court would simply be required to determine whether the individual had been a member of a designated organization and had therefore perjured himself in signing the oath. Had the Court in Douds adopted this analysis, it would have found the disclaimer required of union officers unconstitutional as a bill of attainder.

\section{CONCLUSION}

The Court's adoption of a procedural due process basis for its bill of attainder doctrine would have a profound impact on the permissible scope of antisubversive legislation. The Court would, in effect, be telling Congress that it cannot impose penalties on individuals solely because of their membership, past or present, in the Communist Party, so-called subversive organizations or other unpopular political groups. This would be a hard pill for Congress to swallow, for its typical response to the Communist threat during the past two decades has been to enact precisely the type of statutes which the restated bill of attainder doctrine would strike down. This is the course of pohtical expediency, but it has been followed at the expense of personal liberties. History teaches that in periods of political unrest the normal legislative response is to direct its great power at the political dissident. The lesson to be derived from history is that the bill of attainder prohibition, when placed on a solid doctrinal basis, can be an effective protection against sucl abuses.

The bill of attainder doctrine suggested in this Comment would not be an obstacle to all antisubversive legislation. As the Brown decision said:

We do not hold ... that Congress cannot weed dangerous persons out of the labor movement, any more than the Court held in Lovett that subversives must be permitted to hold sensitive government positions. Rather, we make agam the point made in Lovett: that Congress must accomplisl such results by rules of general applicability. ${ }^{215}$

The attainder prohibition also will not correct all possible abuses in antisubversive legislation. It will simply assure that Congress does not subvert normal judicial processes in legislation directed at political unorthodoxy and the politically unorthodox.

Charles H. Wilson, Jr.

215381 U.S. at 461. 